\title{
Protein hydrolysate as a component of salinized soil in the cultivation of Ageratum houstonianum Mill. (Asteraceae)
}

\author{
Renata Matraszek ${ }^{1 *}$, Barbara Hawrylak-Nowak ${ }^{1}$, Mirosława Chwil ${ }^{2}$ \\ 'Department of Plant Physiology, University of Life Sciences in Lublin, Akademicka 15, 20-950 Lublin, Poland \\ ${ }^{2}$ Department of Botany, University of Life Sciences in Lublin, Akademicka 15, 20-950 Lublin, Poland
}

\begin{abstract}
The aim of the present study was to evaluate the possibility of using a protein hydrolysate, Hemozym N-K 4.5-6, as a component of salinized soil in the cultivation of flossflower (Ageratum houstonianum Mill., Asteraceae). The experiment was focused on the yield and decorative value of A. houstonianum, grown under different concentrations of $\mathrm{NaCl}$ and/or Hemozym. Ageratum houstonianum plants were grown in the soil under different $\mathrm{NaCl}$ salinity (EC: 0.28 - as control or 3.25 $\mathrm{dS} \mathrm{m} \mathrm{m}^{-1}$ - salt stress) or/and Hemozym dose $\left(0,0.07\right.$ or $\left.0.14 \mathrm{ml} \mathrm{kg}^{-1}\right)$. The results of the experiment imply that $A$. houstonianum is sensitive to salinity. The application of Hemozym to both unsalinized and salinized soils caused an increase in the yield of the plant organs (roots, stems, leaves, and inflorescence), the number of leaves, and the chlorophyll content without significant changes in the carotenoids. Moreover, an increase in the number and size of first-order inflorescences (heads) as well as more intensive flower color were observed. Thus, it can be stated that the protein hydrolysate studied can be a beneficial component of both salinized and unsalinized soils in the cultivation of A. houstonianum.
\end{abstract}

Keywords: Ageratum houstonianum; decorative value; Hemozym; protein hydrolysate; salt stress

\section{Introduction}

Increased levels of soil salinization, which may occur continuously or periodically, are a growing problem worldwide and the most dangerous is salinity caused by sodium $\left(\mathrm{Na}^{+}\right)$ and chloride $\left(\mathrm{Cl}^{-}\right)$ions [1]. Currently, approximately $20 \%$ of the world's cultivated lands and nearly half of all irrigated lands are affected by excessive salinity [2]. Soil salinity can result from either geochemical processes or anthropogenic activities. In the natural environment, salinity occurs in coastal areas, marshes and arid regions where evaporation surpasses rainfall. Other natural processes that cause soil salinity are the weathering of rocks, the dissolution of minerals, and the decomposition of organic matter. Anthropogenic soil salinization is mainly a consequence of mining sector activities, waste disposal from the soda and metallurgy industry, the use of salt for clearing snow from roads and sidewalks as well as the use of waste combustion and steel in road construction. The status of soil salinity is also influenced by crop irrigation water from naturally saline water bodies and improper plant mineral nutrition, whether due to the use just one type of fertilizer or overfertilization [3].

\footnotetext{
* Corresponding author. Email: renata.matraszek@up.lublin.pl
}

Handling Editor: Elżbieta Weryszko-Chmielewska
The consequences of high soil salinity are physiological disorders in plant development. The deleterious effects of salinity on plants are associated with the following factors: $(\boldsymbol{i})$ low osmotic potential of soil solution (water stress); (ii) nutritional imbalance and disturbing ionic homeostasis (ionic stress); (iii) specific ion effect (salt stress); (iv) increased production of reactive oxygen species - ROS (oxidative stress), or a combination of these factors [4-6].

Due to the deteriorating conditions of plant growth, there is a tendency to seek out and implement new effective technologies for restoration of degraded areas, including increasing the productivity of saline soils. Therefore, maintaining plant growth under adverse environmental stress conditions is a major challenge for modern horticulture. One of the products that may have a positive effect on plants under stress is the protein hydrolysate Hemozym N-K 4,5-6. This multifunctional fertilizer provides the roots with mineral nutrients as well as stimulates the activity of beneficial microorganisms in the rhizosphere, which improves the utilization of sparingly available macronutrients, for example phosphorus (P) [7]. Hemozym can be used during the whole life cycle of fruit, vegetable and flower crops. However, its effectiveness may vary depending on the season, growth stage and the type of crops. Some studies have demonstrated that Hemozym has a bio-stimulating effect, enhancing foliage and flower colors as well as prolonging the shelf life of fruits 
and vegetables [8,9]. Nevertheless, the effect of Hemozym on plants growing under stress conditions is still poorly understood.

Flossflower (Ageratum houstonianium Mill.) is a perfect solution for an area near a driveway, a hill, even a mailbox near the road. This is an excellent species for use in carpetbedding, also in combination with other annual flowers of contrasting colors. Ageratum houstonianium is often used for planting in flowerbeds and urban green lawns as well as in areas with high salinity. The subject of this study was concentrated on the possibility of using Hemozym N-K 4.5-6 as an amendment of salinized soil in the cultivation of A. houstonianium.

\section{Material and methods}

\section{Characteristics of Hemozym N-K 4.5-6}

Hemozym N-K 4.5-6 (FARPROMODENA S.P.A., Via Ghiarole, 72-41057 Spilamberto, Italy) is an innovative liquid organic-mineral fertilizer obtained through natural microbiologically controlled fermentation of beef blood and stabilized with potassium phosphate. Fermented blood proteins are subjected to hydrolysis that produces low molecular weight peptides ( $<10000 \mathrm{Da})$ and free amino acids, easily absorbed through the roots. The final heat treatment of this product eliminates microorganisms and ensures complete hygiene. The composition of Hemozym N-K 4.5-6 is as follows: total nitrogen $(\mathrm{N})-4.5 \%$, organic nitrogen $(\mathrm{N}$ org. $)-4.5 \%$, water soluble potassium $\left(\mathrm{K}_{2} \mathrm{O}\right)-6 \%$, organic carbon $(\mathrm{C})-17 \%$ with the $\mathrm{C} / \mathrm{N}$ ratio -3.8 , and iron $(\mathrm{Fe})-$ $100 \mathrm{mg} \mathrm{l}^{-1}$. The high-performing and total organic nitrogen in Hemozym (about 95\%) is absorbed by plants, whereas in the case of inorganic fertilizers a major part of the nitrogen is lost through volatility and soil leaching $[8,9]$.

\section{Plant material and growth conditions}

Five-week-old flossflower (Ageratum houstonianium Mill.) seedlings, obtained from the Department of Ornamental Plants and Landscape Architecture, University of Life Sciences in Lublin, were cultivated 10 weeks in solid cultures (one plant for a 1-kg pot) with a commercial potting mix ("Hollas" from Pasłęk, Poland) of different fractions of decomposed sphagnum peat moss, PGMix hydrofertilizer containing macro- and micronutrients as well as chalk. The content of organic matter in this substrate exceeds $85 \%$, the volume of air was approximately $25 \%$, and the $\mathrm{pH}$ was about 6.2. This growing medium meets the nutritional requirements of medium feeders. One day before the seedlings were planted, the growing medium, i.e., substrate, was differentiated by the level of $\mathrm{NaCl}\left(0.60 \mathrm{~g} \mathrm{~kg}^{-1}\right.$ - the natural content in the substrate, i.e., control, or $6.00 \mathrm{~g} \mathrm{~kg}^{-1}$ - salt stress), electrical conductivity (EC; respectively, 0.28 or $3.25 \mathrm{dS} \mathrm{m}^{-1}$ ), and Hemozym dose (0, 0.07 or $0.14 \mathrm{ml} \mathrm{kg}^{-1}$ of the substrate). $\mathrm{NaCl}$ was introduced as $1 \mathrm{M}$ solution, so in the treatments 6 $\mathrm{g} \mathrm{kg}^{-1} 102 \mathrm{~cm}^{3}$ per pot of the solution were used. The EC was measured with a conductometer (Solu bridge CC-317). The lower dose of Hemozym corresponded to the one recommended by the producer for ornamental plant cultivation. The application of Hemozym to unsalinized and salinized substrate during the establishment of the experiment did not change significantly the $\mathrm{NaCl}$ and $\mathrm{EC}$ value (data not shown). The experiment was conducted in an air-conditioned phytotron at the Department of Physiology, University of Life Sciences in Lublin. Seedlings were grown for ten weeks under salt stress or/and Hemozym under controlled conditions: temperature $25 / 20^{\circ} \mathrm{C}$ (day/night), photoperiod of $15 \mathrm{~h}$, photosynthetic photon flux density (PPFD) of $400 \mu \mathrm{mol} \mathrm{m}^{-1}$ $\mathrm{s}^{-1}$, and relative humidity of $60-65 \%$. Throughout the plant growth period, the soil moisture content was maintained at $60 \%$ FWC (full water capacity).

\section{Determination of growth parameters and \\ photosynthetic pigment concentrations}

At the end of the experiment, i.e., after ten weeks of seedlings growing under different levels of salinity or/and Hemozym, the fresh weight (FW) of the individual plant organs (roots, stems, leaves, and inflorescence), main stem height, number of leaves, and abundance of flowering, i.e., the number and size of the first- and second-order inflorescences (heads and umbels) were estimated. Moreover, inflorescence coloration and plant turgor were observed.

To determine the photosynthetic pigment concentration, fresh leaf samples were collected from the middle part of the plant and homogenized in $80 \%$ acetone. The chlorophyll $a$ $(\mathrm{Chl} a)$ and $b(\mathrm{Chl} b)$ as well as total carotenoid concentrations were determined spectrophotometrically following the procedures of Lichtenthaler and Wellburn [10].

\section{Statistical analysis}

The two $\mathrm{NaCl}$ levels were combined with the three $\mathrm{He}$ mozym concentrations in a two-factorial experimental design with eight replications per treatment and one plant per replication. The experiment was replicated twice over the time. All the data were subjected to a two-way analysis of variance (ANOVA), with the salinity level and Hemozym dose recorded as factors. The means were separated by Tukey's multiple range test at $P<0.05$ and the result of the statistical analysis presented in the figures represents the effect of the interaction of salinity level and Homozym dose.

\section{Results}

Salt stress (EC $3.25 \mathrm{dS} \mathrm{m}^{-1}$ ) markedly decreased FW (roots, leaves, and inflorescence), plant height, number of leaves, and concentrations of photosynthetic pigments, and reduced the number and size of first-order inflorescences (heads) of A. houstonianium grown without Hemozym addition (Fig. 1-Fig. 3). Poor coloration and rapid drying up of inflorescences were observed (Fig. 4a,d). Furthermore, salt stress caused wilting symptoms (Fig. 4a,d).

The supplementation of the natural, i.e., unsalinized, soil (EC $0.28 \mathrm{dS} \mathrm{m}^{-1}$ ) with the protein hydrolysate $(0.07$ or $0.14 \mathrm{ml} \mathrm{kg}^{-1}$ ) had a positive influence on the biomass of the A. houstonianium organs, elevated the number of leaves, raised the chlorophyll concentration, and increased florescence (the number and diameter of heads and as well as their improved coloration; Fig. 1-Fig. 3, Fig. 4a-c). The application of Hemozym, depending on its dose, caused a 

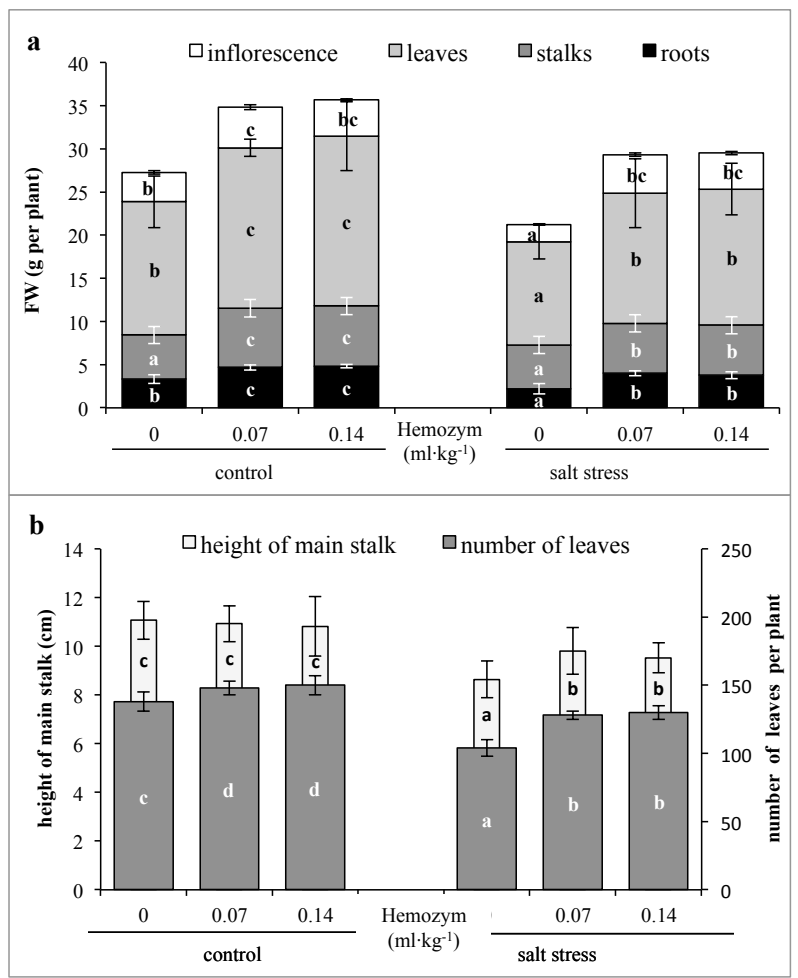

Fig. 1 Biomass of different organs (a) and the biometric parameters of vegetative organs (b) in Ageratum houstonianum depending on salinity and Hemozym dose. The mean values $( \pm S D)$ for each parameter followed by different letters indicate significant differences between treatments according to the Tukey's multiple range test.

40 and $24 \%$ increase in the number of heads and increased their diameter by 16 and $18 \%$ (Fig. 2).

The application of Hemozym to salty ground had a positive impact on the yield of A. houstonianium and its decorative value (Fig. 4d-f). The leaves, apart from their increased number (by about 23-25\%; Fig. 1b), were characterized by a higher concentration of both Chl $a$ and Chl $b$ (Fig. 3) in comparison with plants growing under salt stress. The decorative value was also manifested by the intense coloration of inflorescences as well as more abundant flowering. Furthermore, a significant increase in the number of heads in umbels (about 7 to $20 \%$; Fig. 2a,b), a larger diameter of heads ( 23 to $41 \%$; Fig. 2 c) as well as an increase in the main stem height (by 14 to 10\%; Fig. 1a) were found after application of Hemozym and this increase was much more pronounced for the dose of 0.07 than for $0.14 \mathrm{ml} \mathrm{kg}^{-1}$.

It was found that the application of Hemozym to both unsalinized and salinized soil significantly increased chlorophyll accumulation without changing the carotenoid level. In all experimental treatments, the $\mathrm{Chl} b$ concentrations increased more than those of Chl $a$. Under salt stress, the Chl $a$ level increased by $18-20 \%$ and $\mathrm{Chl} b$ by $29-30 \%$ after application of Hemozym, regardless of its dose (Fig. 3).

It is worth to stress that no general tendency of increasing values of most of the parameters measured was observed with increasing the Hemozym dose (from 0.07 to $0.14 \mathrm{ml}$ $\mathrm{kg}^{-1}$; Fig. 1-Fig. 3).
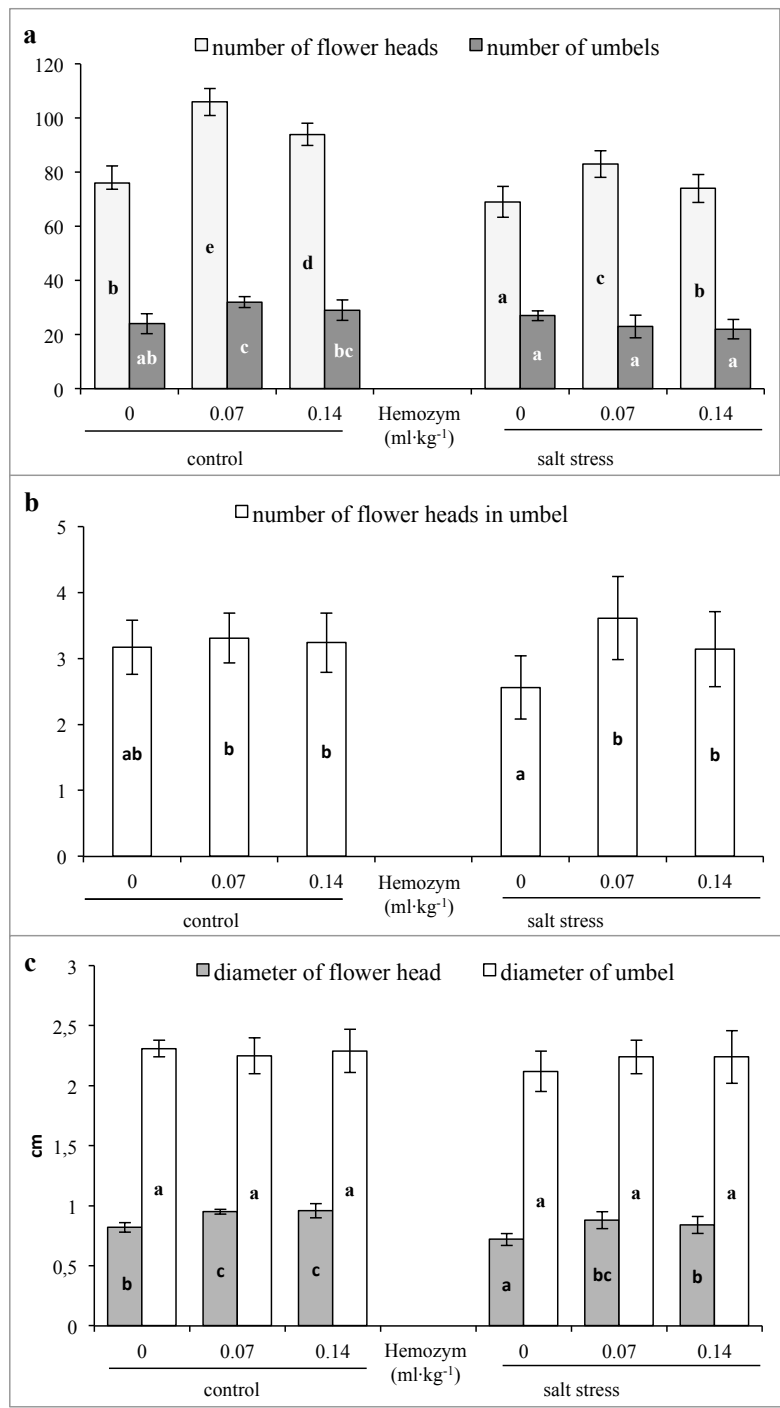

Fig. 2 The flowering parameters of Ageratum houstonianum depending on salinity and Hemozym dose. The mean values $( \pm S D)$ for each parameter followed by different letters indicate significant differences between treatments according to the Tukey's multiple range test.

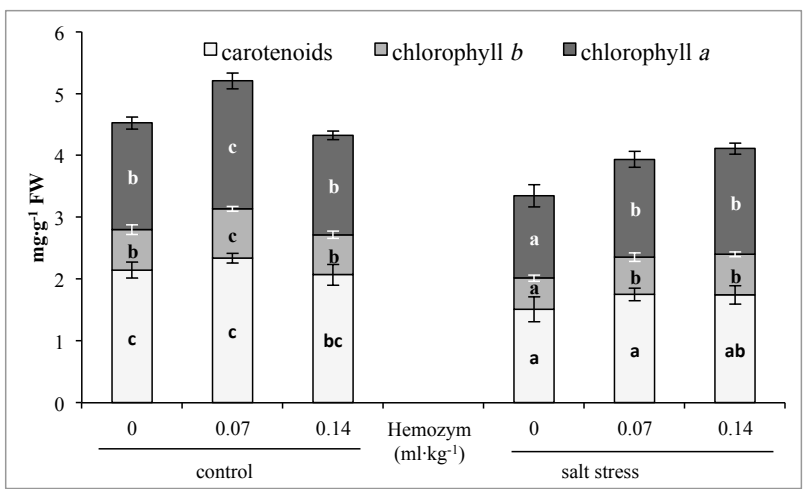

Fig. 3 The concentration of photosynthetic pigments in the leaves of Ageratum houstonianum depending on salinity and Hemozym dose. The mean values $( \pm S D)$ for each pigment class followed by different letters indicate significant differences between treatments according to the Tukey's multiple range test. 


\section{Discussion}

In the present study, under conditions of salt stress (3.25 $\mathrm{dS} \mathrm{m}^{-1}$ ) disorders in vegetative growth and irregularities in reproductive growth of $A$. houstonianium occurred. Similar findings were also reported by Rehman et al. [11] in Rosa hybrida L. and by Liu et al. [12] for Lycopersicon esculentum Mill. Wilting symptoms observed for A. houstonianium plants can be a consequence of disturbances in plant water homeostasis (osmotic stress). The salinity level changes the physical status of water molecules, thereby changing their interactions with proteins and cell membranes [13-16]. A high concentration of salts in the rhizosphere decreases water phytoavailability, due to high osmotic forces retaining water in the soil solution. As a consequence of limited water uptake, the turgor decreases and cell elongation is inhibited. The inhibition of root growth, which was also observed in our experiment, is an additional reason for restriction of water uptake. The excess of $\mathrm{Na}^{+}$in the soil may cause $\mathrm{K}$ deficiency due to the competition of these ions resulting in disturbances of plant water management [1]. The reduced biomass of ornamental plants under salt stress was also observed by Chaparzadech et al. [17] in Calendula officinalis L. and Cornish et al. [18] in Chrysanthemum morifolium L.

The level of salinity used in this experiment was 2-4 dS $\mathrm{m}^{-1}$, which is thought to cause a yield decrease in species very sensitive to salt stress [19]. Similar criteria were also adopted for ornamental plants according to the US Salinity Laboratory classification. Taking into account the EC value of the nutrient solution, five plant categories were identified: sensitive (0-3 dS m $\mathrm{m}^{-1}$ ), moderately sensitive (3-6 dS $\left.\mathrm{m}^{-1}\right)$, moderately tolerant $\left(6-8 \mathrm{dS} \mathrm{m}^{-1}\right)$, tolerant (8-10 dS $\left.\mathrm{m}^{-1}\right)$, and highly tolerant $\left(>10 \mathrm{dS} \mathrm{m}^{-1}\right)$ [20]. Based on the growth parameters and plant vitality, Zuryak et al. [21] revealed that Begonia is sensitive, Plectranthus, Geranium and Chlorophytum are moderately sensitive, but for example Aurocaria heterophylla, Asparagus densiflorus and Hibiscus rosasinencsia are considered as salt tolerant species [22]. Weinhold and Scharpf [23] also reported varying tolerance of ornamental plants to increased concentrations of $\mathrm{Na}^{+}$and $\mathrm{Cl}^{-}$. They showed very strong growth inhibition of Saintpaulia and Primula above 400-500 $\mathrm{mg} \mathrm{Cl}^{-} \mathrm{l}^{-1}$ of substrate. Moreover, they found a growth reduction in Pelargonium when $\mathrm{Cl}^{-}$concentrations exceeded $880 \mathrm{mg} \mathrm{l}^{-1}$, whereas the growth of Petunia was unaffected up to $1000 \mathrm{mg} \mathrm{Cl}^{-} \mathrm{l}^{-1}$. The obtained critical values for $\mathrm{Na}^{+}$were as follows $\left(\mathrm{mg} \mathrm{Na}^{+} \mathrm{l}^{-1}\right.$ of substrate): Pelargonium 780; Begonia 550; Petunia 540; Primula 140. Taking into account the above-mentioned data as well as the results of our study, A. houstonianium may be classified as a salt-sensitive species.

The decrease in the chlorophyll content under conditions of salt stress shown in our experiment may be attributed to increased chlorophyllase activity, pigment-protein complex instability and/or salt ions interfering with proteins, which are involved in chlorophyll biosynthesis [24].

The negative effects of salinity on plants observed in the present experiment included growth reduction, with the oldest leaves rolling, withering, dying and falling off (Fig. 4). This is a defense mechanism against excessive salinity which is widely described in the literature [25]. Similar to our study, the investigations conducted by Wrochna et al. [26] revealed that increased salt concentration (4-32 g $\mathrm{NaCl} \mathrm{l}^{-1}$ ) caused withering and falling off of leaves as well as lower fresh and dry biomass of Amaranthus, Atriplex and Tamarix. Moreover, they showed an increase in $\mathrm{Na}^{+}$, $\mathrm{Cl}^{-}$and free $\mathrm{Ca}^{2+}$ concentrations, which caused an increase in the membrane permeability and efflux of $\mathrm{K}^{+}$. It proves the aforementioned disturbances in the uptake of essential elements, consequently leading to the decay of vegetative organs $[4,5]$. The consequences of disorders in vegetative growth of $A$. houstonianium were irregularities in reproductive growth. Under salt stress, reduced flowering efficiency was observed. It was manifested by a small number of flower buds. Consequently, inhibition of inflorescence formation and less intense inflorescence coloration, a reduced number of heads and a decrease in head diameter as well as rapid drying up were shown (Fig. 2, Fig. 4). Similar observations were made by Devitt and Morris [27] for Agerathum houstonianium Mill. at $\mathrm{EC}=0.8 \mathrm{dS} \mathrm{\textrm {m } ^ { - 1 }}$ as well as for Nerium oleander L. and Bougainvillea Comm. ex Juss. at EC $=4.5 \mathrm{dS}$ $\mathrm{m}^{-1}$. Moreover, many results confirm that the number and size of inflorescences in ornamental plants are negatively affected by salt stress (e.g., Sonneveld and Voogt [28], Rehman et al. [11]).

Salt stress influenced almost all the biometric and physiological parameters of $A$. houstonianium estimated in the present experiment. These parameters are widely proposed for evaluation of the decorative value of ornamental plants [29,30].

The increase in plant biomass after Hemozym application may be due to the fact that this protein hydrolysate not only contains essential nutrients, but also allows for better utilization of nutrients found in the soil by plants, without changing the soil saturation. Similarly to the application of Hemozym to unsalinized soil, better growth, habit and flowering were obtained by Kunka and Nowak [31] when Campanula carpatica plants were fertilized with Basacote Plus 6M. Furthermore, the Pentakeep fertilizer, which is produced in Japan, positively affected the growth of chrysanthemums, accelerating their growth rate and the fresh weight of the plants as well as increasing the number and diameter of heads [32]. Data similar to our results were obtained by Wraga and Dobrowolska [33] in examining the impact of micronutrients from the Actisil fertilizer on two garden pansy cultivars. Pansy plants sprayed with the Actisil fertilizer were characterized by a higher decorative value; they had dark green, stiff and firm rosette leaves and the plants were low in height and spreading.

The present study showed that Hemozym application to salty soil had a positive impact on the yield and decorative value of $A$. houstonianium. The number of leaves as well as the photosynthetic pigment concentration increased. Furthermore, the study found intense inflorescence coloration, more abundant flowering, a significant increase in the number of first- and second-order inflorescences, a larger diameter of heads, and an increase in main stem height. The phenomenon of increased chlorophyll accumulation in plants cultivated in both unsalinized and salinized soils, as observed in this study, may be explained by the addition of extra $\mathrm{Fe}$ - one of the ingredients of the protein hydrolysate. 

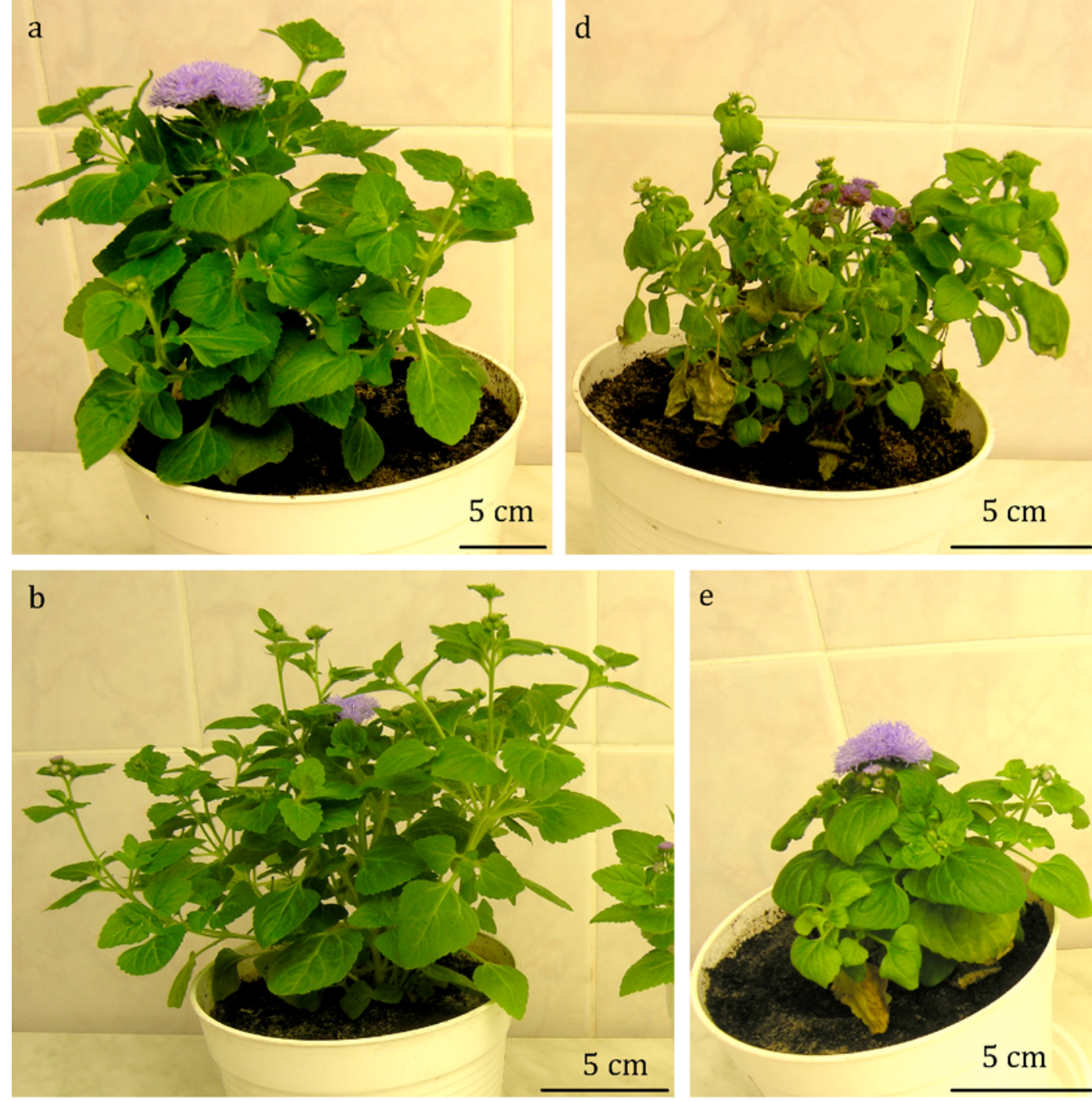

e
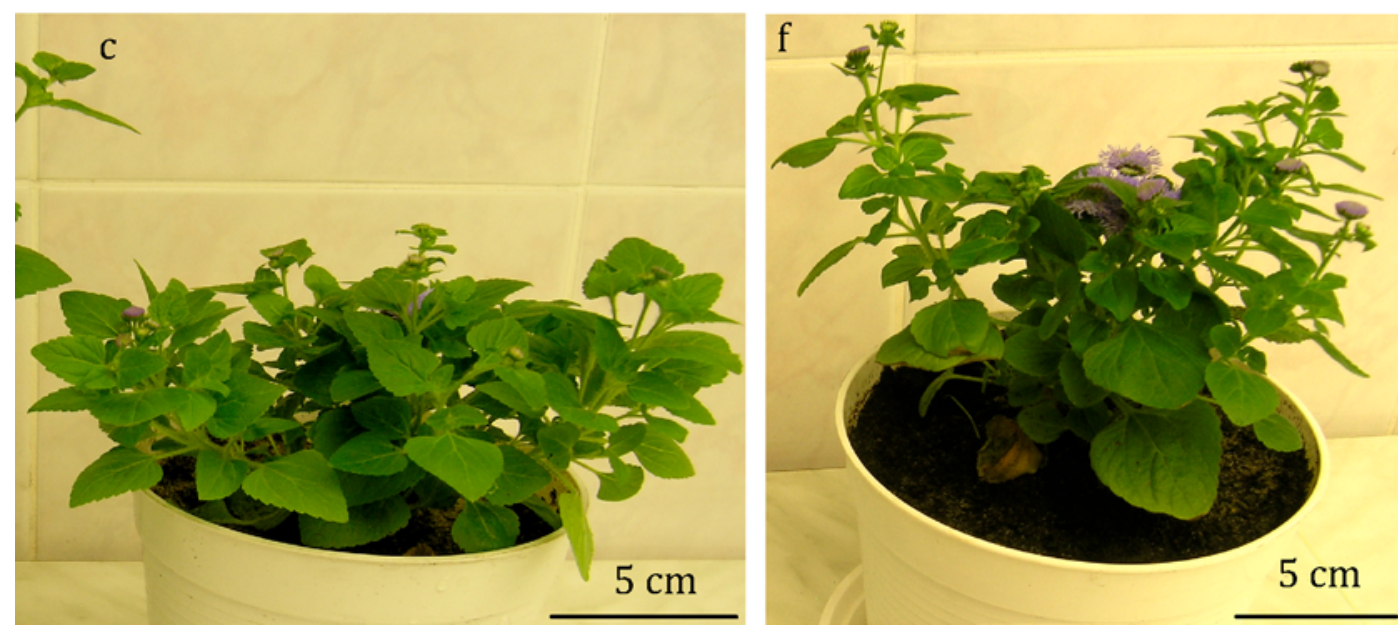

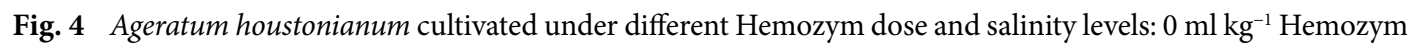
+ EC $0.28 \mathrm{dS} \mathrm{m}^{-1}$ (control; a); $0.07 \mathrm{ml} \mathrm{kg}^{-1}$ Hemzoym + EC $0.28 \mathrm{dS} \mathrm{m}^{-1}$ (b); $0.14 \mathrm{ml} \mathrm{kg}^{-1}$ Hemozym + EC 0.28 $\mathrm{dS} \mathrm{m}{ }^{-1}(\mathbf{c}) ; 0 \mathrm{ml} \mathrm{kg}{ }^{-1}$ Hemozym + EC $3.25 \mathrm{dS} \mathrm{m}^{-1}(\mathbf{d}) ; 0.07 \mathrm{ml} \mathrm{kg}{ }^{-1}$ Hemozym + EC $3.25 \mathrm{dS} \mathrm{m}^{-1}(\mathbf{e}) ; 0.14 \mathrm{ml} \mathrm{kg}^{-1}$ Hemozym + EC $3.25 \mathrm{dS} \mathrm{m}^{-1}$ (f).

Hemozym contains a low amount of Fe, which is a heme porphyrin type of a quite similar structure as chlorophyll. Although Fe is not a constituent of chlorophyll, it is necessary for chlorophyll biosynthesis [34].
Similarly to the application of Hemozym to salinized soil, the study on mealycup sage conducted by Nowak and Kunka [35] revealed a positive impact of compost amendment of growing substrate on alleviating the toxic effect of salinity. 
They observed better growth as well as improved visual quality of leaves, an increase in the number of flowers, and an accelerated flowering period.

To conclude, the results of the present study revealed that A. houstonianium plants are quite sensitive to salinity. Salt stress caused wilting, decreased FW of plant organs, a reduced number of leaves and concentration of photosynthetic pigments, and a decrease in the number and size of first-order inflorescences (heads) as well as it caused their worse coloration. The addition of Hemozym ( 0.07 or 0.14

\section{Acknowledgments}

The authors would like to thank Marta Turniak, who is Sales/Logistic Manager at P.H. AGRO-PROMES, for providing Hemozym N-K 4.5-6 samples produced by Farpromodena (Italy). This research was financially supported by the Polish Ministry of Science and Higher Education.

\section{Authors' contributions}

The following declarations about authors' contributions to the research have been made: idea of the study, statistical analysis: RM; writing of the manuscript, laboratory analysis: RM, BHN, MC; conducting vegetative research: BHN; references: MC.

\section{Competing interests}

No competing interests have been declared.

\section{References}

1. Parida AK, Das AB. Salt tolerance and salinity effects on plants: a review. Ecotoxicol Environ Saf. 2005;60:324-349. http://dx.doi. org/10.1016/j.ecoenv.2004.06.010

2. Zhu JK. Plant salt tolerance. Trends Plant Sci. 2001;6:66-71. http:// dx.doi.org/10.1016/S1360-1385(00)01838-0

3. Yadav S, Ifran M, Ahmad A, Hayat S. Causes of salinity and plant manifestation to salt stress: a review. J. Environ Biol. 2011;32:667-685.

4. Hussain TM, Chandrasekhar T, Hazara M, Sultan Z, Saleh BK, Gopal GR. Recent advances in salt stress biology - a review. Biotechnol Mol Biol Rev. 2008;3:8-13.

5. Parvaiz A, Satyawati S. Salt stress and phyto-biochemical responses of plants - a review. Plant Soil Environ. 2008;54:89-99.

6. Bañón S, Miralles J, Ochoa J, Sánchez-Blanco MJ. The effect of salinity and high boron on growth, photosynthetic activity and mineral contents of two ornamental shrubs. Hortic Sci. 2012;39(3):188-194.

7. Ligorio AM, Ferrara M, Nigro F, Ippolito A. Evaluation of activity of liquid organic fertilizers, Hemozym NK4.5-6 and Hemozym BIO N5, on the growth of biocontrol agents. J Plant Pathol. 2011;93(4 suppl):S4.25-S4.62.

8. Comia RA. Efficacy test for Hemozym 4.5-0-6 as fertilizer for banana (Musa sapientum cv. Lakatan) [Internet]. 2011 [cited yyyy mmm dd]; Available from: http://agro.farpro.it/layout/upload/Prova_Sperimentazione_Banana.pdf

9. Comia RA. Efficacy test for Hemozym BIO N5 as fertilizer for pechay (Brassica rapa) [Internet]. 2012 [cited yyyy mmm dd]; Available from: http://agro.farpro.it/layout/upload/Pechay_plant_Test.pdf

10. Lichtenthaler HK, Wellburn AR. Determination of total carotenoids and chlorophyll $a$ and $b$ of leaf extracts in different solvents. Biochem Soc Trans. 1983;603:591-592. http://dx.doi.org/10.1042/bst0110591

11. Rehman AR, Riaz R, Iqbal M, Shafi J, Ahmad W. Responses of different morphological attribute of Rosa hybrida L. cv. Kardinal to saline water irrigation. Environ Ecol Res. 2014;2(1):21-26.

12. Liu FY, Li KT, Yang WJ. Differential response to short-term salinity stress of heat-tolerant cherry tomato cultivars grown at high temperatures. Hortic Environ Biotechnol. 2014;55(2):79-90. http:// dx.doi.org/10.1007/s13580-014-0127-1

13. Läuchli A, Lüttge U, editors. Salinity: environment - plants $\mathrm{ml} \mathrm{kg}^{-1}$ ) to both unsalinized and salinized soil increased the biomass of the organs, turgor and number of leaves, and chlorophyll concentration. Moreover, an increase in the number and size of heads as well as their better coloration were observed.

Therefore, it can be stated that Hemozym N-K 4.5-6 can be a good component of salinized and unsalinized soils in the cultivation of $A$. houstonianium. Between the two studied Hemozym doses, its lower concentration $\left(0.07 \mathrm{ml} \mathrm{kg}^{-1}\right)$ was the most effective.

- molecules. Dordrecht: Springer Kluwer Academic Publishers; 2007. http://dx.doi.org/10.1007/0-306-48155-3

14. Munns R, Tester M. Mechanisms of salinity tolerance. Annu Rev Plant Biol. 2008;59:651-681. http://dx.doi.org/10.1146/annurev. arplant.59.032607.092911

15. Deinlein U, Stephan AB, Horie T, Luo W, Xu G, Schroeder JI. Plant salt-tolerance mechanisms. Trends Plant Sci. 2014;19(6):371-379. http://dx.doi.org/10.1016/j.tplants.2014.02.001

16. Gupta B, Huang B. Mechanism of salinity tolerance in plants: physiological, biochemical, and molecular characterization. Int J Genomics. 2014;2014:701596. http://dx.doi.org/10.1155/2014/701596

17. Chaparzadech N, D’Amico ML, Khavari-Nejad RA, Izzo R, NavariIzzo F. Antioxidative responses of Calendula officinalis under salinity conditions. Plant Physiol Bioch. 2004;42(9):695-701. http://dx.doi. org/10.1016/j.plaphy.2004.07.001

18. Cornish K, King AI, Reid MS, Paul JL. Role of ABA in stress induced water loss from potted chrysanthemum plants. Acta Hortic. 1985;167:381-386. http://dx.doi.org/10.17660/ActaHortic.1985.167.41

19. Kotuby-Amacher J, Koenig K, Kitchen B. Salinity and plant tolerance [Internet]. 2000 [cited yyyy mmm dd]; Available from: https://extension.usu.edu/files/publications/publication/AG-SO-03.pdf

20. Miyamoto S. Salt tolerance of landscape plants common to the southwest [Internet]. 2008 [cited yyyy mmm dd]; Available from: http://riogrande.tamu.edu/reports/2008/tr316.pdf

21. Zuryak R, Tabbarah D, Banbukin L. Preliminary studies on the salt tolerance and sodium relations of common ornamental plants. J Plant Nutr. 1993;16:1309-1316. http://dx.doi. org/10.1080/01904169309364614

22. Skiminia CA. Salt tolerance of ornamentals. Combined Proceedings of the International Plant Propagators' Society. 1980;30:113-118.

23. Weinhold F, Scharpf HC. Tolerance of ornamental plants to salt, sodium and chloride in potting substrates containing compost made of separately collected organic residues. Acta Hortic. 1997;450:221-228. http://dx.doi.org/10.17660/ActaHortic.1997.450.26

24. Jaleel CA, Sankar B, Sridharan R, Panneerselvarm R. Soil salinity alters growth, chlorophyll content, and secondary metabolite accumulation in Catharanthus roseus. Turk J Biol. 2008;32:79-83.

25. Parks GE, Dietrich MA, Schumaker KS. Increased vacuolar $\mathrm{Na}^{+} / \mathrm{H}^{+}$ exchange activity in Salicornia bigelovii Torr. in response to $\mathrm{NaCl}$. J Exp Bot. 2002;53:55-65. http://dx.doi.org/10.1093/jexbot/53.371.1055

26. Wrochna M, Gawrońska H, Gawroński SW. Effect of salt stress on fresh and dry matter production and accumulation of $\mathrm{Na}^{+}, \mathrm{K}^{+}, \mathrm{Ca}^{2+}$, $\mathrm{Mg}^{2+}, \mathrm{Cl}^{-}$ions in selected species of ornamental plants. Acta Agrophys. 2006;793:755-785.

27. Devitt DA, Morris RL. Morphological response of flowering annuals to salinity. J Am Soc Hortic Sci. 1987;112:951-955.

28. Sonneveld C, Voogt W. Studies on salt tolerance of some flower crops grown under glass. Plant Soil. 1983;74:41-52. http://dx.doi. org/10.1007/BF02178738

29. Dartigues A. The problem of the salinity for ornamental plants grown in pots and containers: determination and interpretation. Acta Hortic. 1982;126:203-212. http://dx.doi.org/10.17660/ActaHortic.1982.126.25 
30. Kücükahmatler $\mathrm{O}$. The effect of salinity on yield and quality of ornamental plants and cut flowers. Acta Hortic. 2002;573:407-414. http://dx.doi.org/10.17660/ActaHortic.2002.573.49

31. Kunka M, Nowak JS. The effect of Basacote Plus on the growth and flowering of (Campanula carpatica JACQ) cultivated in pots. Zesz Probl Postępów Nauk Rol. 2009;53:413-418.

32. Watanabe K, Tanaka T, Hotta Y, Kuromoch H, Takeuchi I. Improving salt tolerance of cotton seedlings with 5 -aminolevulinic acid. J Plant Growth Regul. 2000;32:91-104. http://dx.doi. org/10.1023/A:1006369404273

33. Wraga K, Dobrowolska A. The estimation of effect of Actisil on morphological traits and decorative value of seedlings two garden pansy cultivars from Fancy groups. Part I. Plants growth and leaves size. Rocz Akad Rol Pozn. 2007;383(41):229-233.

34. Smith GA, Witty M. Heme, chlorophyll and bilins: methods and protocols. New York, NY: Springer Verlag; 2008.

35. Nowak J, Kunka M. The effect of salinity, mycorrhizal inoculation and compost supply on growth and flowering of mealycup sage 'Blue Victory' (Salvia farinacea Benth.). Zesz Probl Postępów Nauk Roln. 2009;539:551-559.

\section{Hydrolizat proteinowy jako komponent podłoża zasolonego w uprawie Ageratum houstonianum Mill. (Asteraceae)}

\section{Streszczenie}

Celem prezentowanej pracy była ocena możliwości zastosowania hydrolizatu białkowego Hemozym N-K 4.5-6 jako komponentu podłoża zasolonego w uprawie żeniszka (Ageratum houstonianum Mill.). Założenia eksperymentu koncentrowały się na oszacowaniu plonu i wartości tego gatunku w warunkach różnych koncentracji $\mathrm{NaCl}$ i/lub Hemozymu. Rośliny żeniszka meksykańskiego rosły w warunkach zróżnicowanego poziomu zasolenia $\mathrm{NaCl}$ (EC: 0.28 - kontrola lub $3.25 \mathrm{dS} \mathrm{m}^{-1}$ - stres solny) i/lub (0, 0.07 lub $\left.0.14 \mathrm{ml} \mathrm{kg}^{-1}\right)$. Rezultaty badań wskazują, że żeniszek meksykański jest dość wrażliwy na zasolenie. Aplikacja Hemozymu zarówno do podłoża niezasolonego jak i zasolonego powodowała zwyżkẹ plonów poszczególnych organów (korzeni, łodyg, liści i kwiatostanów), liczby liści i zawartości chlorofilu bez wyraźnych zmian w poziomie karotenoidów. Ponadto stwierdzono zwiększoną liczbę i rozmiary kwiatostanów pierwszego rzędu (koszyczków) oraz lepsze wybarwienie kwiatów. Można wnioskować, że zastosowany w badaniach hydrolizat proteinowy jest dobrym komponentem podłoża zasolonego jak i niezasolonego w uprawie żeniszka meksykańskiego. 